Article

\title{
Even When No One Is Looking: Students' Perceptions of Social Work Professions. A Case Study in a Northern Ireland University
}

\section{Denise MacDermott ${ }^{\text {D }}$}

School of Applied Social and Policy Sciences, Faculty of Arts, Humanities and Social Sciences, Magee Campus, Ulster University, Derry-Londonderry BT48 7JL, UK; dj.macdermott@ulster.ac.uk

Received: 3 July 2019; Accepted: 2 September 2019; Published: 4 September 2019

\begin{abstract}
Public perceptions, increased scrutiny and successive governments' reshaping and attempting to define what is and what is not social work has eroded the progressive and radical force of the profession. This article explores how students' perceive the profession and presents evidence from a small-scale study conducted in a Northern Ireland University with 37 undergraduate social work students and 25 postgraduate student social workers (training-as-practice educators) on their perceptions of the characteristics of a professional social worker. A quantitative research design was used, consisting of a face-to-face survey distributed to respondents following an input on the Place Model, (Clarke, 2016). Respondents also shared their perceptions in relation to Freidson's (2001) three logics: professionalism, bureaucracy and the free market, with Ternary graphs and word clouds used as a novel way to present this data. Several themes emerged as important characteristics of social work professionals including reliability, accountability, ethics and appearance. At the other end of the scale, respondents identified unprofessional, de-personalised and cynical as the least aspirational qualities of the profession.
\end{abstract}

Keywords: social work education; students' perceptions; professional identity; higher education; Northern Ireland

\section{Expectations of Being a Professional: Reflections from a Service User Perspective}

Social workers often engage in lone working, meeting clients, completing assessments, risk management tasks and making decisions about resources. They are expected to consistently adhere to professional standards and ethics. One wonders how does a professional social worker act when no one is looking? The example below offers an insight into the power dynamics which can exist in the working relationships between social workers and clients.

When I retire I plan to embark on a second career as a 'secret social worker'. My rationale for this second 'career' is grounded in an experience I had several years ago. At short notice, I was asked to accompany a woman who felt anxious about being called to the gateway team for a meeting with a social worker. Gateway is a social work service in Northern Ireland for children and families provided by the Health and Social Care Trusts. It is the first point of contact and is tasked with providing an immediate response to safeguard children. Ms A. had contacted social services following the breakdown of her relationship with her husband following 20 years of domestic violence. They had two teenage children who were currently residing with their mother since leaving the family home. Their father wanted them to return to his care. When we arrived at the office, we were directed to the board room and asked to wait for the social worker. I had been at the gym beforehand and wore a tracksuit. On entering the room, the social worker introduced himself and sat down at the head of the table. The social worker explained the purpose of the meeting was to gather information to help 
him complete an initial assessment. He then advised the woman that he had meet her husband the previous day and that her husband was a lovely man. The woman became upset. I leaned forward to speak and the social worker placed his hand in a stop position and stated "I don't want to hear from you. I need to hear from Ms. A." At this point I decided it was time to declare to the social worker that:

1. I was a qualified social worker.

2. I was an experienced practice teacher and professional supervisor.

3. It was clear he was a newly qualified social worker.

4. This meeting was now over.

The social worker became flustered and was visibly shocked when I shared this information and requested he leave the room to locate his line manager. Shulman [1] suggests in work practice we expect that practitioners can 'tune in' to their sense of self and the 'unique life histories of others' National Occupational Standards, [2]. This skill enables social workers to get a sense of what the client/ service user/survivor's potential feelings about the interaction with the social worker might be. As professionals, social workers in Northern Ireland must adhere to Standards of Conduct and Practice NISCC [3]. In this example, this did not happen. From the outset, the environment of a board room was not the best place to hold an initial meeting. Furthermore, the information relating to domestic violence was known to the social worker as the woman had referred herself to the gateway team. The statement in relation to Ms A's husband lacked thought or insight into domestic violence or the power dynamics occurring within the interaction. The use of a hand gesture to try and silence someone from speaking was completely unacceptable. When the manager explored the incident with the social worker he referred to the fact that I didn't tell him I was a social worker. He thought I was a friend of Ms A and his focus was to gather the information he needed to complete the assessment. Should that make a difference to the way in which he interacted with Ms A? Where does professional integrity sit within this example? What would have happened had I not called an end to the interview?

\section{Introduction}

This experience has stayed with me and it is one I share with my students. when we consider their career trajectories-this year, the discussion was also provoked by a presentation of Clarke's (2016) Place Model [4], focused around the question 'What does a professional social worker look like even when no one is watching?'

This paper is written by a professional social worker, a profession whose complexities are writ large in this parable which has become central to the author's teaching and mentorship of students. The empirical data presented within this paper will focus on respondents' views of

1. How students perceive their profession;

2. Differences between undergraduate and postgraduate professional values;

3. Student's perceptions on the relative importance of markets, professionalism and bureaucracy (Freidson's three logics) [5].

Clarke's (2019) [6] definition of professional (trustworthy experts) was presented to the students to consider as were Eliot Freidson's (2001) [5] three 'logics'—professionalism, markets/capitalism and bureaucracy/managerialism. The introductory sections of the paper also provide some local context for the study. This paper draws on data collected from a university in Northern Ireland with two student cohorts. Undergraduate student responses $(n=37)$-these students were sampled in week nine of their first semester of teaching on the accelerated degree programme, which is taught over two years. Postgraduate responses $(n=25)$-these students are studying at master's level to obtain their Practice Teaching (practice educator) award to supervise students on placement. Schon [7] coined the phrase 'tacit knowing in action' to try and capture what professionals do when they struggle to find the exact language to describe what they do. This resonates with social work as a profession which is often intuitive and where mastery is developed and fine-tuned over time by building on one's personal and 
professional knowledge and expertise. Ferguson [8] concurs with Briggs [9] that social work education must enable students to learn to 'sit with uncertainty' and learn about the complexities of 'the self' and the narratives of their career-long journeys.

\subsection{Context: Regulatory Bodies}

Social work regulation is devolved in the United Kingdom-England (Health and Care Professions Council), Wales (Social Care Wales), Scotland (Scottish Social Services Council) and Northern Ireland (Northern Ireland Social Care Council). These four bodies operate within a Memorandum of Understanding characterised by principles of cooperation. In addition, each of the Councils will have their own Standards of Conduct which students and practising social workers must adhere to. Overarching within all of this is the wider agreed Global definition of the Social Work Profession, as set out by the International Federation of Social Workers [10]:

"Social work is a practice-based profession and an academic discipline that promotes social change and development, social cohesion, and the empowerment and liberation of people. Principles of social justice, human rights, collective responsibility and respect for diversities are central to social work. Underpinned by theories of social work, social sciences, humanities and indigenous knowledge, social work engages people and structures to address life challenges and enhance wellbeing".

A total of $50 \%$ of the social work degree in the UK comprises practice-based learning (International colleagues will be more familiar with the terms field education or field practicum) and this is regarded as the 'signature pedagogy' of the social work profession. Practice-based learning requires structured formal direct observations of practice, in addition to informal observations and feedback from service users, staff, etc., who have worked with the student. Shulman [11] identified signature pedagogies as the fundamental types of teaching through which practitioners are educated for their new professions. Júlíusdóttir [12] (p. 41) posits "the structure of practice placement in the educational process may fulfil two goals; offering practical training while, at the same time, serving the gate keeping function".

The social work profession occupies an evolving landscape which continues to come under public scrutiny as a result of multiple serious case reviews across the United Kingdom such as those which have produced both huge angst and enormous headlines around Victoria Climbié $[13,14]$ David and Samuel Briggs [15]; Toner Report [16]; Daniel Pelka [17]; Hamzah Khan [18]. At an individual level, there is a sense from social work practitioners of 'appreciation starvation' in relation to the pay and status associated with their role. The financial benefits are not comparable with the levels of complex risk associated with decision making in often 'life or death' situations. Social work is increasingly framed around the logics of commerce and efficiency.

\subsection{Context: Freidson's Logics}

As is the case in other professions, Clarke (2019) [6] asserts that many other issues which impact on the professionalism of social workers arise from or are impacted by Eliot Freidson's [5] other two logics—-markets/capitalism and bureaucracy/managerialism. Freidson's [5] third logic of professionalism is a shift away from his earlier work in 1988 [19], which places the professions in a power and privilege vacuum protected from lay interference. This view is softened in his later work, where the third logic imagines a professionalism which can counter managerial and commercial forces and importantly, benefit the quality of care and keep service users at the fore. Ball [20] (p. 1049) describes the markets as 'arrangements of competition and choice, and various forms of privatisations which takes two forms .... endogenous and exogenous modes of privatization'. Ball [20] posits that endogenous privatization introduces the market into the public sector, which results in reshaping public services into businesses. Similarly, examples of exogenous privatisation are present within social work education, with the introduction of Frontline in England, a two-year social work programme for graduates. Frontline consists of five weeks residential training followed by employment in a local authority. Successful completion of the first year qualifies participants as social workers. In 2018, Skills for Care announced the new Social Work Integrated Degree Apprenticeship [21], this has no formal 
entry requirements and it usually takes 36 months to qualify as a social worker. This level of 'mission creep' with the introduction of various social work education providers is moving education away from a public service to a private commodity. In May 2019, Community Care [22] reported that a popular master's in social work programme at an English university was scrapped with the university citing 'changes in the social work landscape'. The university would not be drawn on whether the growing number of fast-track training providers was a factor in the decision to close the programme.

Carey and Foster [23] (p. 258) concur, suggesting that 'the overhaul of social work education with pedagogical services making way to 'reductionist' skills and vocational courses' and the increased role of the private sector in social work alongside the purchaser/provider split are examples of the way in which social work is increasingly fragmented in the UK, Canada and Australia. Van Pelt et al. [24] (p. 278), writing from a Dutch perspective posit that 'social work is considered an open profession, vulnerable to consumerism, capitalism, bureaucratism and to struggles between professionals and managers over control'. Concomitantly, Freidson [5] (p. 181) postulated 'the reality is and should be a variable mix of all three logics, the policy issue being the precise composition of that mix'.

\subsection{Context: Bureaucracy and Managerialism}

Freidson [25] (p. 119) posits 'professional work is defined as specialized work that cannot be performed mechanically because the contingencies of the task vary so greatly from one another that the worker must use considerable discretion to adapt their knowledge'. The issue with professional discretion is that it is unpredictable in achieving results and outcomes within social work practice. Applying managerial direction, organised by rules and regulated by policies and procedures, can seem like the 'quick fix' to increase productivity and achieve results. The continued discourse of focusing on standards, competencies and quality improvement strategies is detracting from what Foucault [26] (p. 117) regards as 'the establishment of a certain objectivity, the development of a politics and a government of the self, and an elaboration of an ethics and practice in regard to oneself'.

Since 2005, social workers in Northern Ireland have had Legal Protection for the Title of Social Worker, making it an offence for an individual to call themselves a social worker or carry out the social worker job role if they are not registered with the governing body NISCC. It is a similar picture across the UK. This offered social workers recognition of status and also, increased power and 'legitimate professional authority', e.g., the power to remove a child from their family and to seek the protection of the court for the child. Under certain circumstances and through joint working with doctors, approved social workers may commit a person with mental ill-health to hospital for a period of assessment without their consent. This legitimacy also requires social workers to be accountable for their actions.

The impact of austerity has borne savage cuts to health and social care budgets in the UK. This has led to a reduction in the number, type and range of professional staff across the UK. Within Northern Ireland, there is an increasing number of social work assistant posts (band 4 salary) employed by the Health and Social Care Trusts via recruitment agencies on a month to month basis. Malin [27] (p. 68) suggests that "the principle neo liberal goal is to 'roll back the frontiers of the state' in a belief that unregulated market capitalism will delivery efficiency, growth and widespread prosperity".

Revalier's [28] research on UK social workers working conditions and wellbeing found that $92 \%$ of respondents were working more hours than they were contracted to, alongside high levels of presenteeism, where employees go into work despite being ill. Within an organizational context, the push from new managerialism within social work has continued to erode the professional identity of practitioners. Martin et al. (p. 378) [29] posit that 'managerialism and markets now occupy territories that were once the exclusive domain of the health professions'. One of the distinctive issues facing the statutory social work profession in Northern Ireland is the increasing use and costs associated with recruitment of social workers through recruitment agencies. The Department of Health completed a survey with social work graduates across Northern Ireland in 2018 to identify students' intentions and aspirations post-graduation. The results identified several areas for concern in relation to statutory workforce planning and development. 
1. The increased use of social workers from recruitment agencies impacts on the security of employment and undermines the ethos of meaningful relationship-based practice between social workers and service users.

2. Newly Qualified Social Workers (NQSWs) at the beginning of their professional careers are receiving conflicting messages from Health and Social Care Trusts that continuity of care and commitment are not core values of 21st century social work practice.

3. A transient NQSW workforce presents difficulties in supporting and supervising them to meet the requirements of their Assessed Year in Employment.

MacDermott and Campbell [30] postulate that the 70\% statutory/30\% voluntary (NGOs) employment split in social work within Northern Ireland has created a focus on statutory social work and has contributed to NGOs social work being viewed as a lesser alternative. Their 2016 research highlighted that $75 \%$ of final-year social work students in Northern Ireland identified an emphasis on statutory social work throughout their studies. Interestingly, in the most recent update of the report for the Improving and Safeguarding Social Wellbeing: A Strategy for Social Work [31], the voluntary sector is mentioned once in relation to a pilot project for looked-after children to measure the quality of the relationship between young people in care and their social workers.

As a seasoned practitioner and practice educator, I have listened to the debate on where real social work takes place for over fifteen years. For students, practice educators and academics there is often a view that statutory fieldwork teams are the place to 'earn your stripes' as a social work professional. This is a troublesome position for all stakeholders in social work education, creating an assumption that the definition of social work rests within statutory agency provision. The influence of welfare state agencies and regulatory bodies in shaping the social work curriculum has contributed to the erosion of radical social work. Scholar et al. [32] (p. 933) suggest that this view of non-traditional placements as being of less value "may encourage students to view themselves as having a poorer deal than their colleagues who were placed in 'real social work settings".

In a climate of increasing bureaucracy, there has been a loss of focus in relationship-based social work, an influence which manifests itself in the production of what Ingram and Smith [33] (p. 4) suggest "became a technical/rational rather than an ethical and relational endeavour ... increasingly framed around following procedure and ensuring compliance". The production of efficient employees who can complete assessments and paperwork within set timeframes, whilst minimising the actual time spent working with families. This approach reduces the opportunities for students to critically consider their professional identity and ways in which they can meaningfully address the impact of structural inequalities and poverty which plague the lives of service users. Ioakimidis [34] comments that new radicalism in social work must be based on five pillars, democracy, empathy, militancy, anti-oppressiveness and structural practice.

\subsection{Context: Social Work as a Profession in Northern Ireland}

In March 2018, there were 5912 social work practitioners registered with the Northern Ireland Social Care Council. These practitioners are employed across a range of settings. The majority of social workers in Northern Ireland are employed by the State. Figures from the Northern Ireland Health and Social Care Workforce Census [35] identified 3766 social workers employed within Health and Social Care Trusts (70\%). The remaining 30\% are employed within the voluntary, education, justice and independent sectors. In the Health and Social Care Trusts, one-third of the registered social workers are over the age of 50 .

Social work in Northern Ireland is unique compared to other parts of the UK with the legacy of the thirty years of 'The Troubles' in which over 3500 people lost their loved ones. Northern Ireland is moving forward as a new and emerging post-conflict contested society. Moreover, the complexities of Brexit and securing a 'deal' which guarantees no hard border between Northern Ireland and our closest neighbours in the Republic of Ireland adds another layer of uncertainty, to the fragile peace citizens of Northern Ireland have had since the Belfast (Good Friday) Agreement in 1998. The complexities of the 
Northern Ireland political landscape illustrate why Northern Ireland remains a divided society in 2019. Manktelow and Lewis [36] (p. 303) comment "In Northern Ireland, being Catholic or Protestant is not just a matter of religious belief and church membership, but an ethnic identity which influences a whole range of social variables". The NISCC Framework Specification for the Degree in Social Work [37] (p. 6) acknowledges this, "the impact of past and current violence, conflict and divisions in Northern Irish society requires particular emphasis in the education and professional development of social work students".

This sentiment is echoed within a recent British Association of Social Work (Northern Ireland) report [38] which highlighted the experiences of social workers working through the Troubles. Looking at the responses from social work education providers during that time, it concluded that during the Troubles, there was a lack of capacity and, perhaps, even a fear of bringing up the conflict within social work education. Furthermore, their research commented that less than half $(47 \%)$ of the respondents said that they received support from their employer when they experienced violence during the Northern Ireland conflict. These experiences included death threats, bomb scares, shootings, bombings and sectarian abuse. It is, therefore, essential that social work students in Northern Ireland are aware of the legacy issues from the Troubles and the transgenerational issues which are present when working with service users, carers and survivors.

The age profile of students applying to study social work is changing, with increasing numbers of school leavers accepting places. Many of these applicants are 'children of the Northern Ireland peace process' and have not experienced or been exposed to 'The Troubles' in their lifetime. Gilligan [39] suggests that student's perceptions of the world are more internalised and increasingly individualistic, and without this experience, it may be that these young social workers are in danger of missing a key part of the unique socio-political jigsaw which underpins so much of life in Northern Ireland some 20 years after the signing of the Belfast (Good Friday) Agreement, which brought the Troubles to an (as yet incomplete) end.

Aligning the market logic with the professional logic is a distinct challenge and one in which the priorities of the State are centre stage. This is a question of supply and demand. Each year there are 260 places available on the qualifying BSc (Hons) social work Degree. These places are shared between two universities, Ulster University and Queen's University, Belfast. The Department of Health in Northern Ireland provides a non-means-tested bursary for social work students at both universities. This is $£ 4500$ per annum, paid in two parts directly to the student. Students domiciled outside Northern Ireland are not eligible to receive this money.

Increasingly, Northern Ireland graduates are accepting employment in the Republic of Ireland as these posts offer more attractive salaries than those of the recruitment agencies which statutory social work trusts in Northern Ireland rely heavily upon. At present, there are not enough social workers to fill the vacancies and the lack of permanency in employment has created an environment in which Northern Ireland universities are 'producing graduates for export'. Martin et al. [29] refers to strategies from seduction to enforcement being employed by managers and commissioners and there is some evidence of this happening in Northern Ireland recently with job offers and permanent contracts available for students on graduation (seduction). This forms part of a strategic approach to reduce the spend on recruitment agencies and close the supply and demand gap. Although one wonders, if this strategy does not prove successful whether the State will take a tougher stance? For example, acceptance of the student bursary equals two years post-qualifying employment within the Health and Social Care Trusts (enforcement).

It is, therefore, timely to identify and explore undergraduate and postgraduate students' perceptions about being a social work professional in the fourth industrial revolution [40]. 


\section{Materials and Methods}

This research employed a quantitative approach with a prepared questionnaire including open and closed questions which asked respondents to describe 'you as a professional' and the key characteristics and expectations of the social work profession. The questionnaire was distributed to two groups of students following a presentation of The Place Model [4]. The data was collected by the author following each presentation. Blaxter [41] define this form of sampling as 'event sampling' —using routine or special events as the basis for sampling. The presentations to students took place at different campus locations dependent on the mode of study—either undergraduate or postgraduate. Grey [42] suggests delivery and collection questionnaires have the advantage of online and postal questionnaires in generating a higher response rate. Participation in the study was voluntary.

Group 1: Undergraduate

BSc (Hons) social work students in semester one of the relevant graduate route programme. These students hold a cognate degree, obtaining a place on the accelerated degree programme (two years).

Group 2: Postgraduate

Postgraduate students completing their practice teaching/practice educator qualification. These students are qualified social workers with three to fifteen-plus years' experience.

Student Survey

A structured questionnaire was distributed to the students after a brief presentation on the Place Model [4]. The questionnaire asked respondents to identify their views of professional characteristics and Freidson's [5] three logics—professionalism, bureaucracy and markets. The response rates are captured below.

Group 1: Undergraduate returned a response rate of $(n=37)$ undergraduate students from a class cohort of 40 .

Group 2: Postgraduate returned a response rate of $(n=25)$ postgraduate students from a class cohort of 33 .

No generalisability is claimed within the results. Respondents ranged from students in their first semester of learning prior to completing their first placement to qualified social work practitioners with fifteen-plus years' experience. Representation from throughout the Island of Ireland was included within the sample.

Ethical Issues

Crow et al. [43] detail the principles of informed consent, which ensures that participants are provided with clear, accessible information about a project, enabling them to make an informed decision on whether or not they wish to participate. Participation in this project is entirely voluntary. Ethical approval was granted by Ulster University Filter Ethics Committee in March 2015 for the duration of the project until 2020. The completed surveys will be stored in adherence with Ulster's Research Governance protocols and will be retained for ten years.

\section{Results}

The data sets are presented within this section. Quantitative results are presented through ternary and bar graphs. The data comparing the professions in respect of Freidson's [5] three logics are displayed in ternary graphs as these facilitate a visual comparison of the data from the valuations of the various parameters. The mean was calculated for each section of the survey and the three means were totaled and converted to percentages of this total using Microsoft Excel. This data was then used to draw up ternary graphs using the Plotly analytic app.

The open-ended questions within the survey enabled respondents to reveal their thoughts on the types of professional they would like to be; most aspirational and least aspirational. A Microsoft Excel table was created to record the frequency of words used in the responses to these open questions. The responses are presented as words clouds within this section to add further context and offer a visual representation to the reader. 


\subsection{Demographic Characteristics of Respondents}

In group one (undergraduate students), the majority of respondents were female $(n=33)$, with the remaining $(n=4)$ identifying as male. The age range of respondents was $21-49$ years. In group two, the majority of respondents were female $(n=22)$, with the remaining $(n=3)$ identifying as male. The age range of group two respondents was 31-62 years.

\subsection{Findings}

The respondents were asked to score their perceived importance of commonly cited characteristics of professionals. These findings are presented below in bar graphs in Figures 1 and 2.

\section{Group 1: Undergraduate}

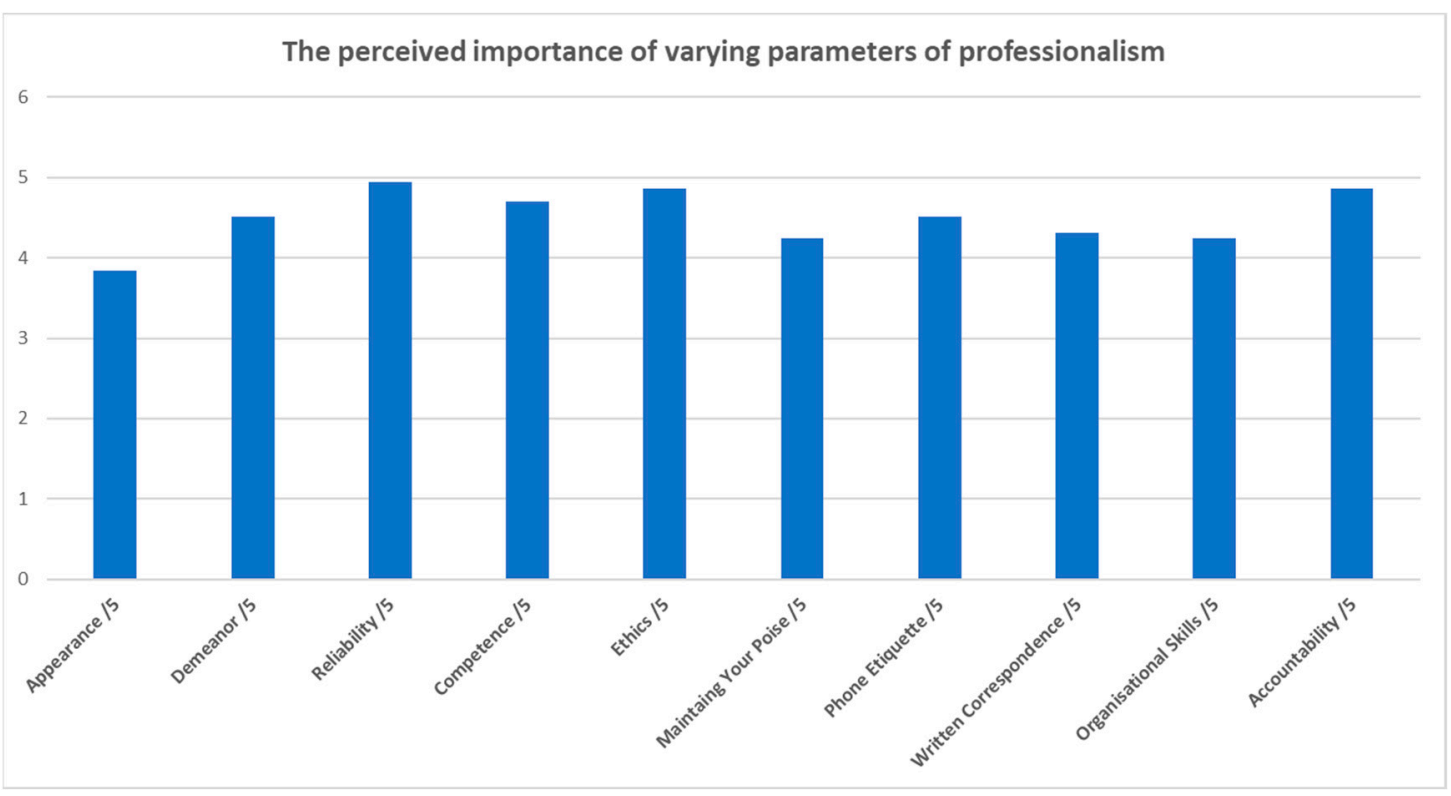

Figure 1. Student social workers perceptions of the varying parameters of professionalism.

Group 2: Postgraduate

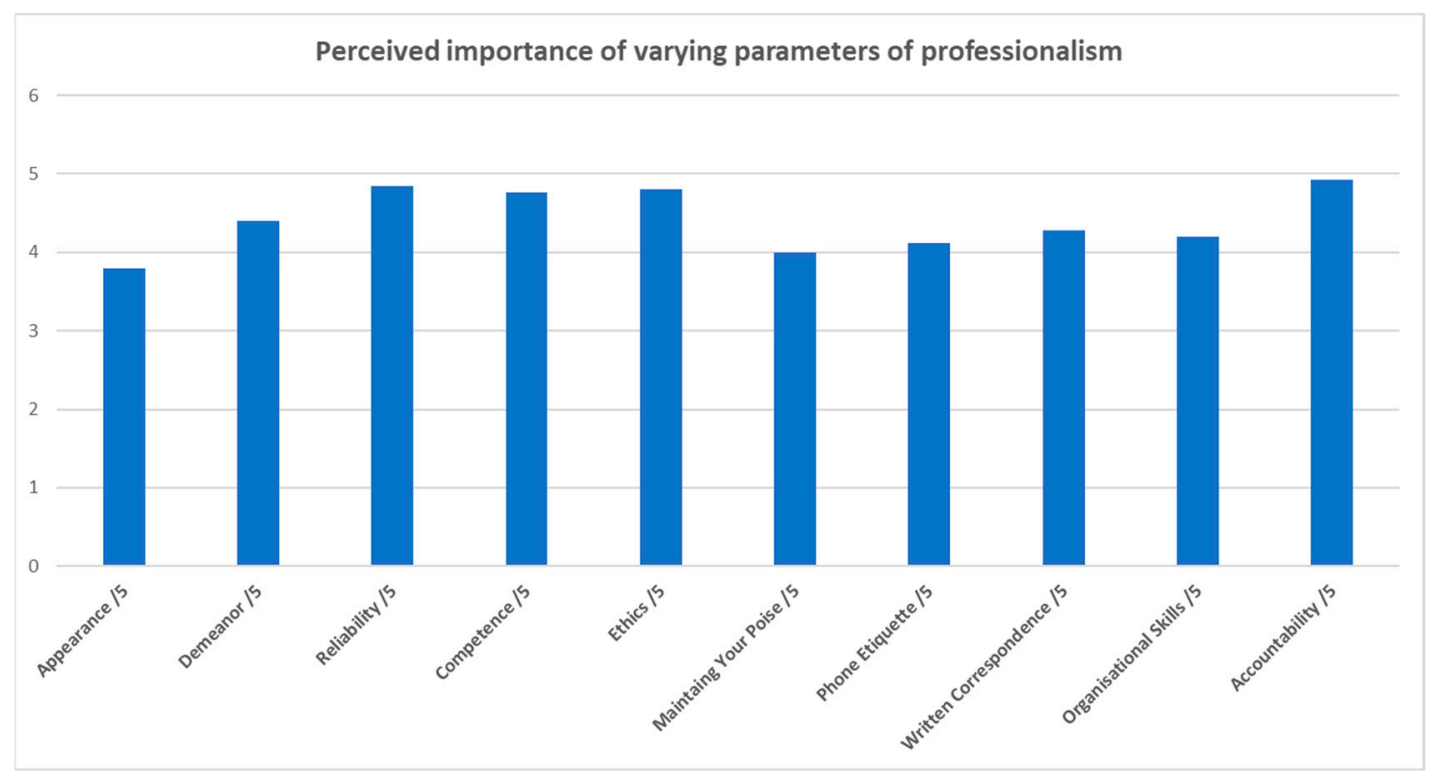

Figure 2. Qualified social workers perceptions of the varying parameters. 
There is remarkable similarity between the views of the members of the two groups here. It is also evident that those aspects of professions which might be deemed most superficial (such as demeanor or appearance) were scored just as highly in importance as the more complex matters such as accountability and ethics.

The survey respondents were asked to contrast professionalism with Freidson's [5] other two logics, bureaucracy and markets. The range of professionals included, Medical Doctor, Lawyer, Journalist, Social Worker, Teacher and Nurse. Respondents were asked to record a score out of 10 for each of the professions. Their responses are illustrated below in Figures 3 and 4 using ternary graphs as a 3D visual of their perceptions of Freidson's three logics.

Group 1: Undergraduate

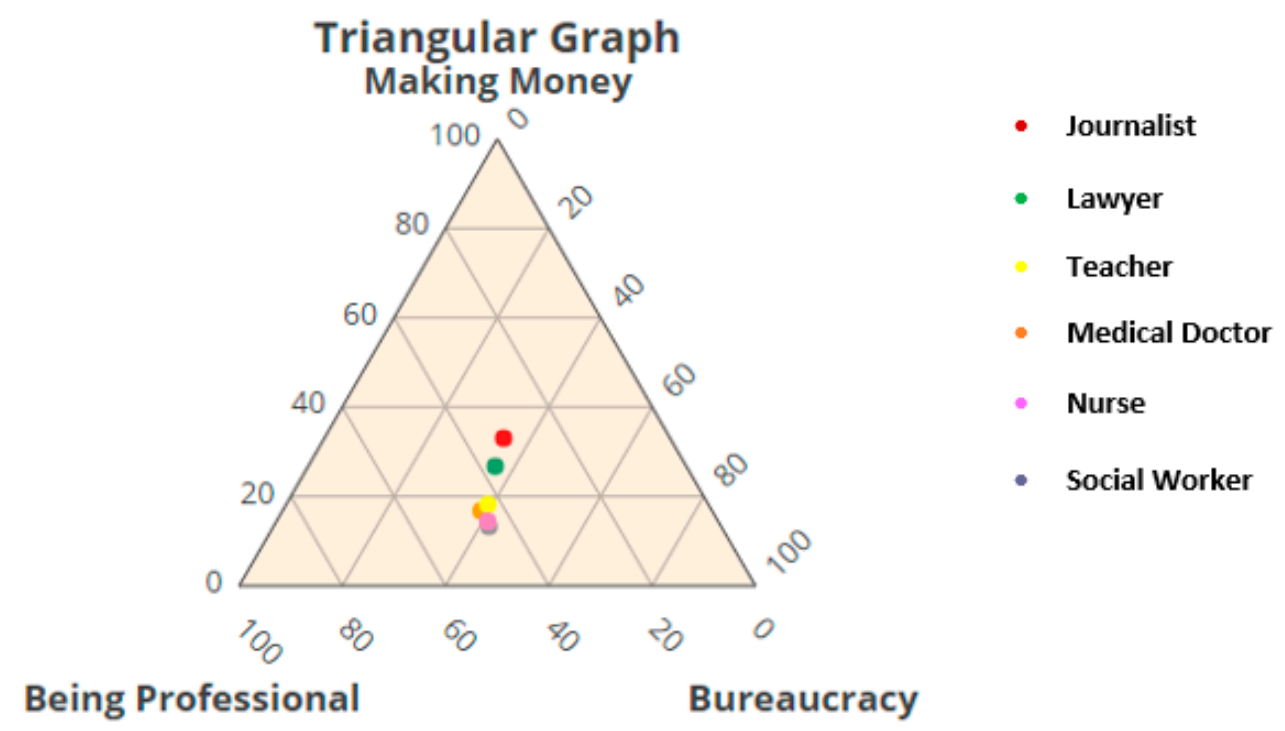

Figure 3. Student Social Workers perceptions of the professions.

Group one respondents identified journalists, lawyers and teachers as professions in which making money is important and readers, clients and students are consumers. Interestingly, those aligned with the helping professions are given almost equal weighting with a strong emphasis on being professional and bureaucracy.

Group 2: Postgraduate

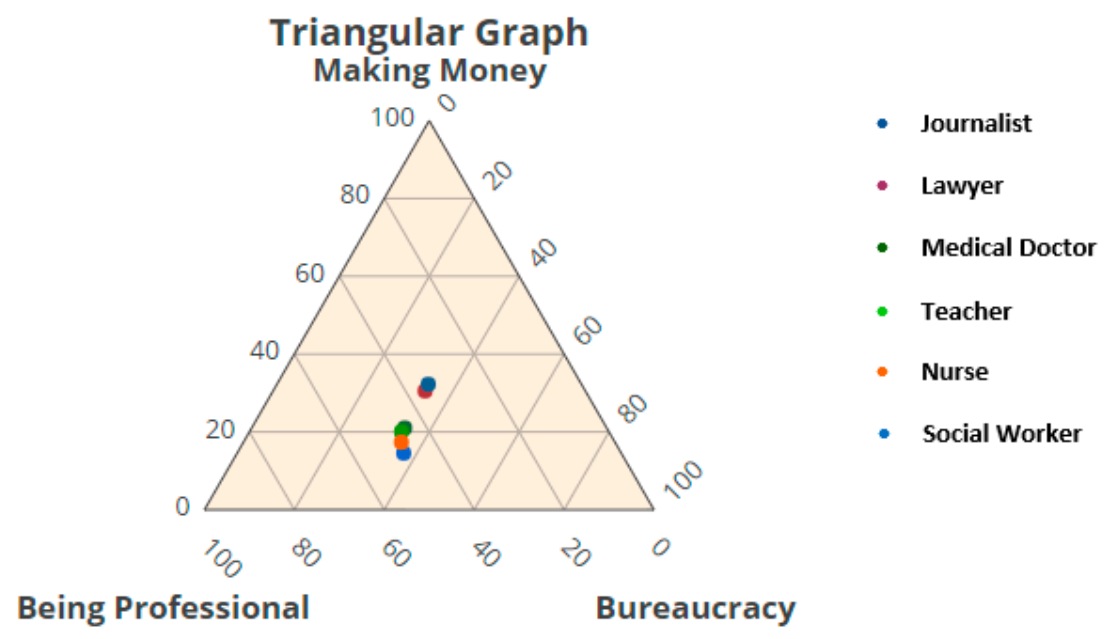

Figure 4. Qualified Social Workers perceptions of the professions. 
Group two respondents identified journalists. It was interesting to note that for both sets of survey respondents (undergraduate and postgraduate), journalists were identified as the professionals most motivated by money. It is interesting, and hardly surprising, that journalists, who have a key role in publicising the perceived deficiencies of social workers in the 'headline' cases, such as those note earlier, are perceived as most motivated by money by both groups.

The open-ended questions in the survey generated a range of responses from both sets of students in relation to the types of professional they would like to be. These responses are presented below as word clouds in Figures 5-11.

Group 1: Undergraduate

\section{Trustworthy \\ Knowledgeable}

Supportive Foir

Approachable Empathetic

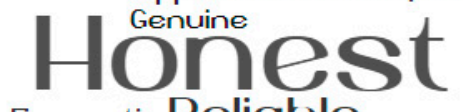

Energetic Reliable

Engaging Committed

Advocate-for-young-people

Professsional

Figure 5. Student Social Worker and the type of professional they would like to be.

Group 2: Postgraduate

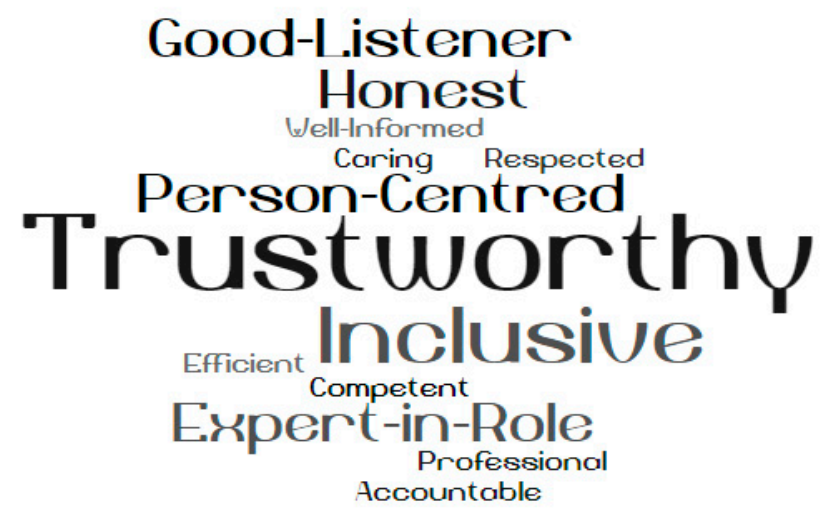

Figure 6. Qualified Social Worker and the type of professional they would like to be. 
Group 1: Undergraduate

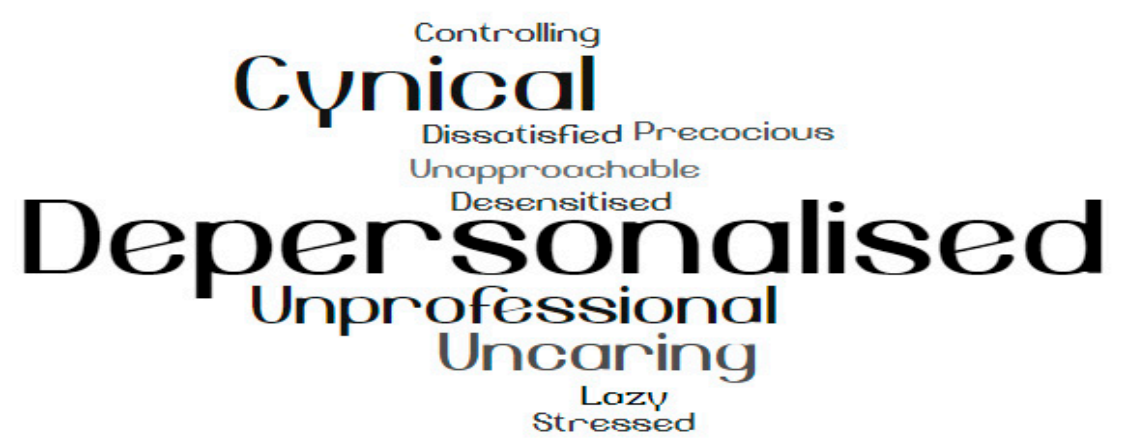

Figure 7. Student Social Worker—Least Aspirational Qualities.

Group 2: Postgraduate

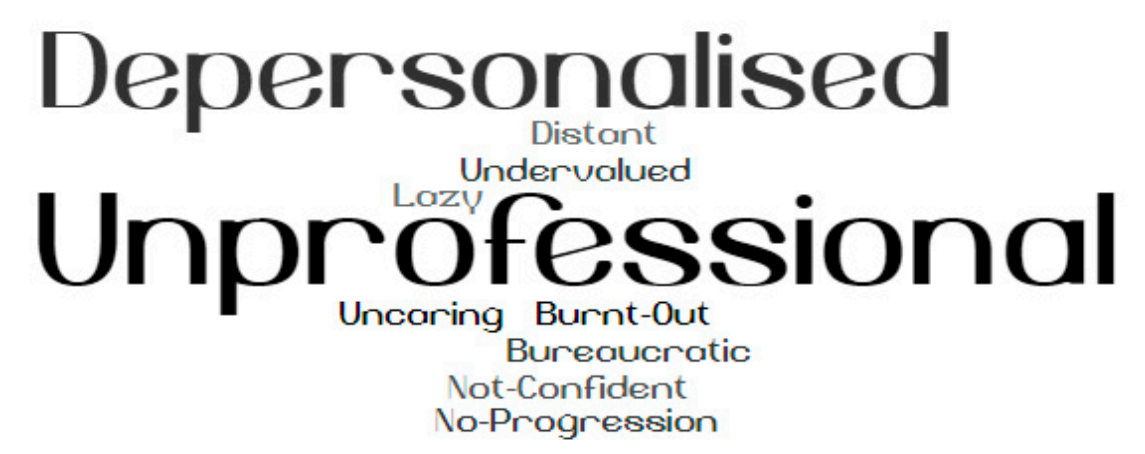

Figure 8. Qualified Social Worker-Least Aspirational Qualities.

In relation to the respondents' views on the least aspirational qualities of a professional social worker, the data revealed similar themes between the two groups.

1. Unprofessional;

2. De-personalised;

3. Cynical. 
Both groups of respondents were asked to identify their most aspirational social work roles. For group one (undergraduate), this is a guess without having had any formal experience of social work practice. Group two (postgraduate) have several years of experience working in direct practice.

Group 1: Undergraduate

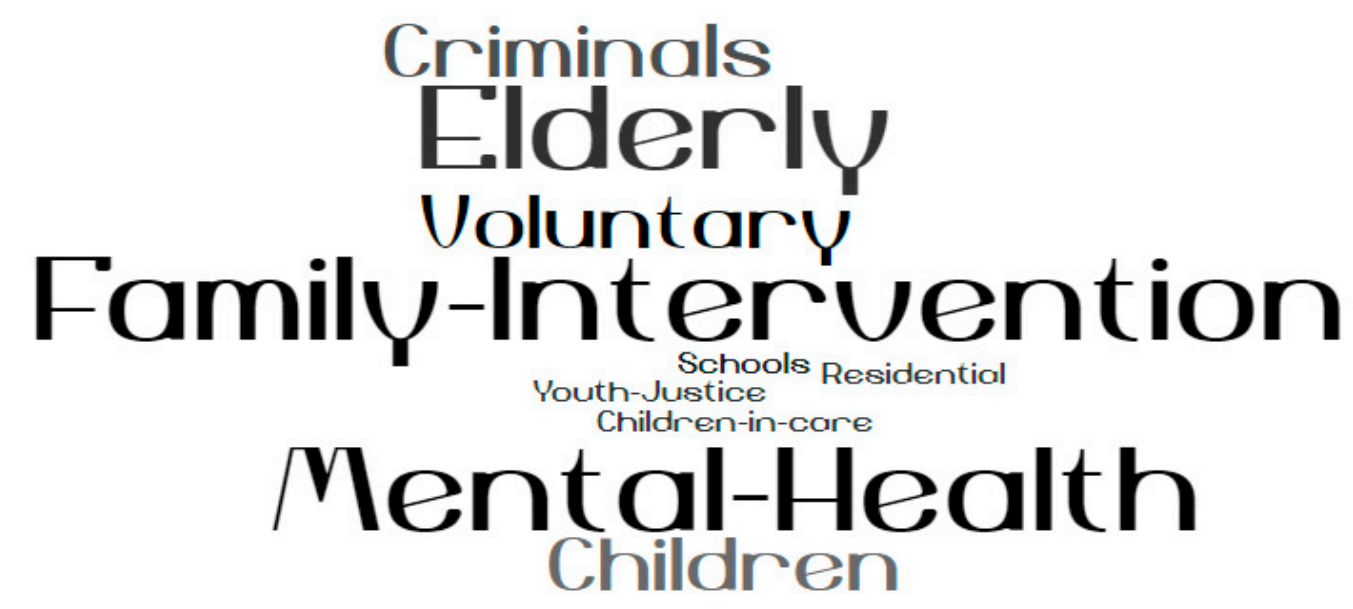

Figure 9. Student Social Workers: Most Aspirational Social Work Roles.

Group 2: Postgraduate

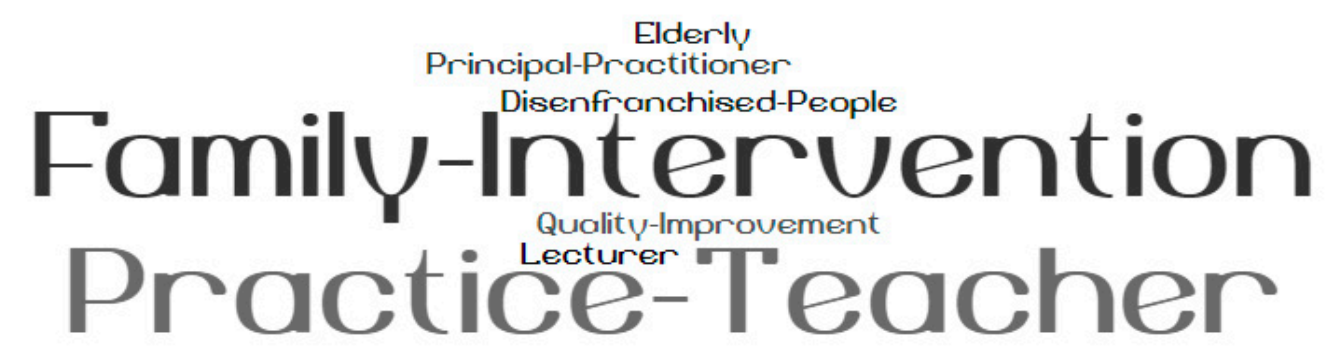

Figure 10. Qualified Social Workers: Most Aspirational Social Work Roles. 
Finally, within this section, respondents were asked to identify their least aspirational roles within social work. Group one (undergraduate) responses are captured below in Figure 11. Group two (postgraduate) did not respond to this question in significant numbers. Their responses are recorded as direct quotes as written on the completed survey.

Group 1: Undergraduate

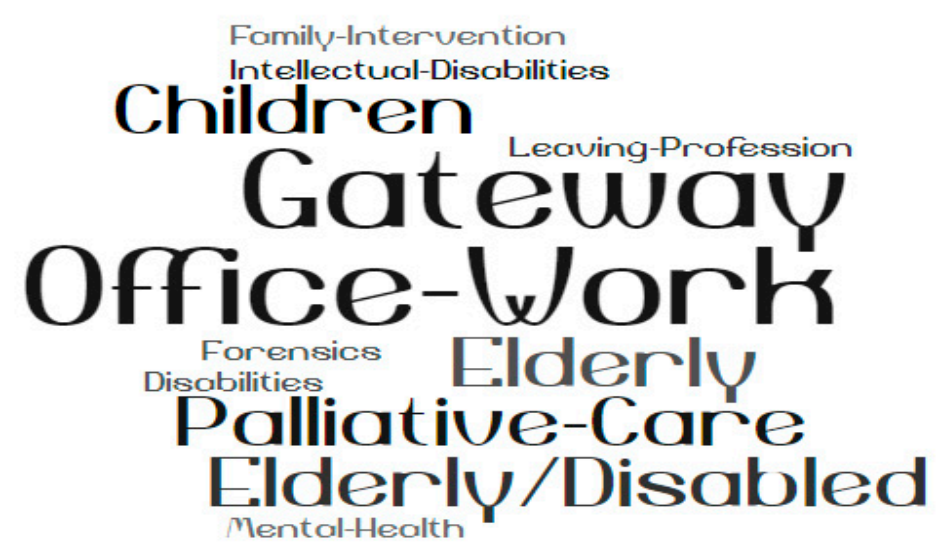

Figure 11. Student Social Workers: Least Aspirational Social Work Roles.

Group 2: Postgraduate

Respondent 24 "The levels of inequality I am witnessing is frightening. My least aspirational role is one in which I don't have a voice to challenge oppression or advocate for Human Rights".

Respondent 22 "A role in which I don't have the time to build relationships with service users".

Respondent 18 "Becoming a manager and being distant from direct practice and the people I work with".

Respondent 15 "Principal Social Worker and being a step removed from practice, struggle to identify with groups on the ground".

Respondent 10 "To be in front line family and childcare for the remainder of my career".

\section{Discussion}

Edmond and Price [44] posit that the definition of professionalism has a particular emphasis on the key aspects of a profession including status, pay, expertise, standards, values and ethics. In this study, it was interesting to note that both groups of respondents-undergraduate and postgraduate-identified similar themes in relation to their perceptions of the types of professional they aspire to be:

1. Trustworthy;

2. Honest;

3. Professional;

4. Good listener.

Moreover, the respondents are at different stages of their professional journey. Group one (undergraduate) completed the survey three weeks prior to finding out where they will be placed for their first practice learning opportunity ( 85 days). The statutory sector currently provides approximately $85 \%$ of social work placements in Northern Ireland with NGOs offering the remainder. Group two (postgraduate) completed the survey during their taught course prior to being allocated a student when 
placement commenced in January 2019. Group two were at the beginning of a new role as 'gatekeeper to the profession', assessing the competence of their allocated student. The role of the practice teacher is complex. They are responsible for helping students to become professional practitioners and to develop the knowledge, skills and values, associated with their professional role and identity [45]. For group two, there is a further challenge as they occupy the dual role of learner and educator and an increased sense of accountability and responsibility about their decision making and assessment. They are also being assessed on their competence to 'pass', to qualify as a practice teacher/practice educator at master's level.

Both groups of respondents (undergraduate and postgraduate) identified the same top three core parameters of perceived importance in professionalism.

1. Reliability;

2. Accountability;

3. Ethics.

In this study, these were the attributes that were ranked as the most important and offered an insight into the respondents' perceptions of the qualities a social work professional should possess. Dillenburger et al. [46] define professional competence as the ability to do something well. Social work students on placement are assessed against a range of social work standards to evidence their competence in direct practice and at the point of graduation, there is an assumption that students are fit to practise. Northern Ireland was the first region in the UK to introduce an additional measure to support Newly Qualified Social Workers (NQSWs), the Assessed Year in Employment (AYE), which recognises the importance of continued formal observation and evidence of knowledge consolidation. It is a similar picture in England with the Assessed and Supported Year in Employment (ASYE), Wales requires NQSWs to complete the Compulsory Consolidation Programme and Scotland is currently developing a probationary year for NQSWs following the Review of Social Work Education [47].

This resonates with the rationale for the continuum of lifelong learning expected of social work professionals. In Northern Ireland, the Professionals in Practice framework is governed by NISCC and requires commitment from registrants to complete continued professional development (CPD) to maintain their registration as social workers. The rationale is to build practitioner expertise and enhance public trust from those who access services. This requirement to improve, enhance and develop specialist and leadership skills is also linked to promotion, career progression and financial incentives, e.g., on completion of their Assessed Year in Employment, social work graduates who are employed by the state move from a Band 5 to Band 6 salary.

The Francis Report [48] (p. 1442) defines candour as "the volunteering of all relevant information to persons who have or may have been harmed by the provision of services whether or not the information has been requested or whether or not a complaint about that provision has been made". In relation to health and social care and particularly, social workers, this is at different stages across the UK. Despite the recommendations of the Francis Report, duty of candour was not introduced in England owing to the 'ethical duty' of honesty within professional regulatory standards. In Scotland, the government introduced duty of candour legislation in 2016 within the Health (Tobacco, Nicotine etc., and Care) (Scotland) Act. In Wales, following consultation, indications are that the statutory duty of candour will be for healthcare providers instead of individual staff. The Donaldson Report [49] in Northern Ireland favoured a duty of candour on organisations. Donaldson's rationale for this was the view that legislation which brought the threat of criminal convictions/sanctions would contribute to a culture of fear instead of openness and transparency.

As a profession, social work has often had to work to justify its inclusion alongside other professions, e.g., medical. The primary reason for this is the 'generalist approach' used within social work whereby practitioners will move across and between methods and models of interventions often reaching for feedback or input from service users, carers and survivors. This impacts on social work's ability to measure its effectiveness and has led to an increased drive to deliver on metrics and outcomes 
and evidence-informed practice to justify the specialist knowledge and professional status of the role. Measurement is a core neo liberal priority. There is growing dissonance between the self-identity of social workers as agents of critical change and their actual role in the technical delivery of neo liberal policies, a sentiment echoed by Garret [50,51].

In this study, both sets of respondents (undergraduate and postgraduate) identified appearance as an important parameter of professionalism. Compared to the more substantial characteristics of reliability, accountability and professional ethics this, at first, seems more superficial. Is this linked to perceptions of professional identity? Or messages from practice? Or the wider influence of a society powered by Instagram and social media? Duncan-Daston et al., in their paper, suggest that social work educators alongside students must be cognisant of the ways in which online profiles impact on their 'professional presence' [52]. Upholding public trust and confidence forms part of the current curriculum for social work in the UK and is embedded within the revised Standards of Conduct for Social Work Students [53]. In Northern Ireland, social work students and qualified practitioners who contravene professional boundaries or NISCC Standards when using social media will be held accountable for their actions, which could include a referral to a 'fitness to practise' panel.

Practice teachers/educators are role models to students in how to be a professional social worker and have a responsibility to ensure students are accountable for competent professional behaviour. Goffman [54] wrote about 'personal front' with reference to how people present themselves within social interactions. An individuals' appearance can often give clues to others about their social status. Do social workers look more professional if they are wearing a suit? Will the quality of the service-user-social worker relationship be aided by formal attire? Or is this about power and influence? Perhaps social work students are receiving conflicting messages between the university campus and the placement site? For example, in social work lectures, students can display their piercings, tattoos and wear shorts or football tops. It is a truism that increasingly universities are focused on the student experience and enhancing metrics by creating inclusive learning landscapes. Davys et al. [55] (p. 341), writing about Occupational Therapists, posits that "part of being a professional is to consider the impact that self-presentation will have on the service user within her or his social context". Contrastingly, Williams et al., writing from a social work perspective, postulate that policies requiring staff to cover up tattoos and piercings are perhaps inconsistent with social work core values, leading to discrimination, stigma and prejudice [56]. Furthermore, within the Northern Ireland context, football or Gaelic Athletic Association jerseys are often associated as a signifier of religious or ethnic identity and are not permitted to be worn in the workplace.

Terum and Heggen [57] conducted a longitudinal study in Norway with social work students. Their research suggests that identification with a profession is an ongoing process and one which reflects on the student's answer to two questions.

1. Who am I?

2. Who do I want to become?

They postulated that access to role models, e.g., lecturers, practice educators (on placement) and peers, forms the social work students' 'professional socialisation', which contributes to the creation of an identity. In this study, the undergraduate students are at an early stage in their professional journey, they are appraised of the common values, ethics, knowledge, skills and values required of the social work profession. Although how these are applied in practice (on placement) will be different given the individual approaches and methods they use. This is, essentially, their internalisation of professional identity and what makes a good social worker? Freidson [5] (p. 84) posits that this 'journey' 'contributes to the development of commitment to the occupation as a life career and to a shared identity, a feeling of community or solidarity among all those who have passed through it'.

Reflecting back to the example at the beginning of this paper with the NQSW and Ms. A, the social worker looked like a professional, (appearance) the meeting was held in a professional environment (boardroom) and the social worker was clear on why the meeting was taking place (purpose). However, 
on that particular day, his interaction with Ms. A was unprofessional and fell significantly below the basic standards the public and the social work profession expect.

The outcome of the 'your husband is a lovely man' scenario was twofold. In the first instance, a referral was made by the social worker's line manager for him to attend training on domestic violence. Furthermore, a meeting between Ms. A, the social worker and his line manager to enable Ms. A to discuss how she felt during that initial meeting was conducted. Strategic Priority 3 of the Learning and Improvement Strategy [58] identifies professional curiosity and the sharing of information and expertise as vehicles to acquire new knowledge skills and qualifications to better meet the needs of service users, carers and survivors. Despite the access to further training and professional supervision, what is unknown is what the social worker actually learned from this experience. Mezirow [59] refers to as the process of making a new or revised interpretation of the meaning of an experience, which guides subsequent understanding and application.

Greenglass [60] identified two forms of coping 'reactive' when stress is managed following a stressful or traumatic event and 'proactive', whereby resources are developed for future use. Both sets of respondents in this study identified similar themes in relation to the least aspirational type of social worker they would want to be as unprofessional, de-professionalised and cynical. Pithouse's views [61] (p. 4) on social work as an invisible professional activity resonates with this, "social work is an inherently 'invisible' trade that cannot be 'seen' without engaging in the workers' own routines for understanding their complex occupational terrain...social workers who visit people in the privacy of their own homes or see them in the office usually do so free from observation and interference by their colleagues, who likewise pursue a similar form of intervention".

Honesty, unequal treatment, failure to demonstrate respect in their interactions with service users and concerns about technical aspects of practice, e.g., breaching confidentiality were the top four categories of complaints raised about social workers in Northern Ireland from 2006-2015 [62]. The voice of service users, carers and survivors in Northern Ireland is fundamental to shaping social work students and qualified practitioners' understanding of the significance of building effective, professional, person-centred relationships which recognise the service user as the expert through experience [63].

\section{Conclusions}

This article has explored students (undergraduate and postgraduate) perceptions of professionalism in social work. As undergraduate students engaged in formal learning to become social work practitioners, they are closely monitored and observed throughout placement to ensure they meet the standards required. The NQSW example in this paper highlights that once qualified, practitioners often engage in social work practice 'unobserved', so whether practitioners are 'getting it right' or displaying poor professional practice, this is occurring without independent observation to corroborate. There is a balance to be achieved as Hordern [64] (p. 6) suggests "expertise is also seen as the capacity to exercise judgement with a degree of autonomy".

The role of the social worker in the age of the fourth industrial revolution has changed. We no longer work in silos. We are required to demonstrate professional meta competencies and work across and between trans-disciplinary teams within the health professions, the private sector and alongside 'nonprofessional' colleagues. Baretti [65] (p. 280) comments that 'being proud to be a social worker expresses something not only about organisational affiliation, but also motivation and the desire to do a decent job'.

In this study, there was remarkable similarity between the two groups of respondents considering that one group of respondents were nine weeks into their professional learning and the other group had extensive social work practice backgrounds. Reflecting on the original research questions on how respondents perceive the profession and in relation to those aspects of professions they deemed important, appearance and demeanor were scored just as highly as highly complex aspects such as accountability and professional ethics. Their responses in relation to perceptions of helping professions 
had a strong emphasis on professionalism and bureaucracy. The challenge within this is how do we 'row back' from how embedded the institutional logics of management and the markets are within professionalism? The demands of social work education within Higher Education is to review, revise and improve the quality to impact on the professional expertise of graduates. Furthermore, that these graduates will remain in the profession long enough to have a positive impact with the individuals and families with whom they work. This raises the question how much occupational control do social work educators have in (re)shaping the curriculum and trying to retain the core values of social work against this backdrop? Ball [20] (p. 1056) posits that 'our professional identity is rooted in our own principles and we must push back against the bureaucracy to hold onto the power to define ourselves, 'who we are and who we might become'.

Funding: This research received no external funding.

Acknowledgments: I would like to thank Stephen Clarke for his technical expertise.

Conflicts of Interest: The author declares no conflict of interest.

\section{References}

1. Shulman, L.S. The Skills of Helping Individuals, Families, Groups and Communities, 4th ed.; Peacock Publishers: New York, USA, 1999.

2. Northern Ireland Social Care Council. National Occupational Standards for Social Work; NISCC: Belfast, UK, 2011.

3. Northern Ireland Social Care Council. Standards of Conduct and Practice for Social Workers; NISCC: Belfast, UK, 2015.

4. Clarke, L. Teacher Status and Professional Learning; Critical Publishing: Northwich, UK, 2016.

5. Freidson, E. Professionalism: The Third Logic; Polity Press: Cambridge, UK, 2001.

6. Clarke, L.; McFlynn, P. All Animals Learn, but Only Humans Teach: The Professional Place of Teacher Educators. Educ. Sci. 2019, 9, 192. [CrossRef]

7. Schon, D.A. The Reflective Practitioner: How Professionals Think in Action; Temple Smith: London, UK, 1983.

8. Ferguson, I. How social workers reflect in action and when and why they don't: The possibilities and limits to reflective practice in social work. Soc. Work Educ. 2018, 37, 415-427. [CrossRef]

9. Briggs, S. Working with troubled adolescents: Observation as a key skill for practitioners. In Observation in Health and Social Care: Applications for Learning, Research and Practice with Children and Adults; Hingley-Jones, H., Parkinson, C., Allain, L., Eds.; Jessica Kingsley: London, UK, 2017; pp. 101-120.

10. International Federation of Social Workers. Available online: https://www.ifsw.org/what-is-social-work/ global-definition-of-social-work/ (accessed on 10 March 2019).

11. Shulman, L.S. Signature Pedagogies in the professions. Daedalus 2005, 134, 52-59. [CrossRef]

12. Júlíusdótti, S. The Emerging Paradigm Shift in Social Work-in the Context of the Current Reforms of European Social Work Education. Soc. Work Soc. 2011, 4, 38-51.

13. Laming, H. The Victoria Climbié Inquiry Report; CM 5730; HMSO: London, UK, 2003.

14. Laming, H. The Protection of Children in England: A Progress Report; HC330; The Stationery Office: London, UK, 2009.

15. Department of Health, Social Services and Public Safety. Review of Health and Social Services in the Case of David and Samuel Briggs; DHSSPS: Belfast, UK, 2003.

16. Department of Health. Independent Review Report of Agency Involvement with Mr. Arthur McElhill, Ms. Lorraine McGovern and Their Children: The Toner Report; DoH: Belfast, UK, 2008.

17. Rogers, M. Daniel Pelka Serious Case Review, Coventry LSCB; Local Government Information Unit/Children's Services Network: London, UK, 2013.

18. Bradford Safeguarding Children Board. A Serious Case Review Hamzah Khan: The Overview Report; Bradford Safeguarding Children Board: Bradford, UK, 2013.

19. Freidson, E. Profession of Medicine: A Study of the Sociology of Applied Knowledge; University of Chicago Press: Chicago, IL, USA, 1988. 
20. Ball, S.J. Neoliberal education? Confronting the slouching beast. Policy Futures Educ. 2016, 14, $1046-1059$. [CrossRef]

21. Institute for Apprenticeships and Technical Education Social Worker (Degree). Available online: https: //www.instituteforapprenticeships.org/apprenticeship-standards/social-worker-degree/ (accessed on 17 June 2019).

22. Community Care, University Halts Social Work Master's Programme to Focus on New Degree Apprenticeships. Available online: https://www.communitycare.co.uk/2019/05/31/university-halts-socialwork-masters-programme-focus-on-new-degree-apprenticeships/ (accessed on 19 June 2019).

23. Carey, M.; Foster, V. Social Work, Ideology, Discourse and the limits of post hegemony. J. Soc. Work 2011, 13, 248-266. [CrossRef]

24. Van Pelt, M.; Hutschemaekers, G.J.M.; Sleegers, P.; Van Hattum, M.J. Education for what? Exploring Directions for the Professionalisation of Social Workers. Br. J. Soc. Work 2015, 45, 278-295. [CrossRef]

25. Friedson, E. Theory of Professionalism: Method and Substance. Int. Rev. Sociol. 1999, 9, 117-129. [CrossRef]

26. Foucault, M. The Ethics of the concern for self as a practice of freedom. In Michel Foucault: Ethics, Sensitivity and Truth: The essential Works of Michel Foucault 1954-1984; Rabinow, P., Ed.; Penguin: London, UK, 1997.

27. Malin, N. Developing an analytical framework for understanding the emergence of de-professionalisation in health, social care and education sectors. Soc. Work Soc. Sci. Rev. 2017, 19, 66-162. [CrossRef]

28. Revalier, J. UK Social Workers: Working Conditions and Wellbeing; Bath Spa University: Bath, UK, 2017.

29. Martin, G.P.; Armstrong, N.; Aveling, E.A.; Herbert, G.; Dixon-Woods, M.P. rofessionalism Redundant, Reshaped, or Reinvigorated? Realizing the Third logic in Contemporary Health Care. J. Health Soc. Behav. 2015, 56, 378-397. [CrossRef]

30. MacDermott, D.; Campbell, A. An examination of student and provider perceptions of voluntary sector social work placements in Northern Ireland. Soc. Work Educ. 2016, 35, 31-49. [CrossRef]

31. Department of Health. Available online: https:/www.health-ni.gov.uk/sites/default/files/publications/health/ social-work-strategy-stage2-progress-report.pdf (accessed on 12 February 2019).

32. Scholar, H.; McCaughan, S.; Mc Laughlin, H.; Coleman, A. 'Why is This Not Social Work?', The Contribution of Non-Traditional Placements in Preparing Social Work Students for Practice. Soc. Work Educ. 2012, 7, 932-950. [CrossRef]

33. Ingram, R.; Smith, M. Relationship-based Practice: Emergent Themes in Social Work Literature; Institute for Research and Innovation in Social Services (IRISS): Glasgow, UK, 2018.

34. The Guardian. A Guide to Radical Social Work. Available online: https://www.theguardian.com/socialcare-network/2016/may/24/radical-social-work-quick-guide-change-poverty-inequality (accessed on 10 March 2019).

35. Department of Health. Northern Ireland Health and Social Care Workforce Census; Department of Health: Belfast, UK, 2018.

36. Manktelow, R.; Lewis, C.A. A Study of the Personality Attributes of Applicants for Postgraduate Social Work Training to a Northern Ireland University. Soc. Work Educ. 2005, 24, 297-309. [CrossRef]

37. Northern Ireland Social Care Council. Framework Specification for the Degree in Social Work; NISCC: Belfast, UK, 2014.

38. Duffy, J.; Campbell, J.; Tosone, C. Voices of Social Work Through the Troubles; BASW (Northern Ireland): Belfast, UK, 2018.

39. Gilligan, P. Well motivated reformists or nascent radicals: How do applicants to the degree in social work see social problems, their origins and solutions? Br. J. Soc. Work 2007, 37, 735-760. [CrossRef]

40. Schwab, K. The Fourth Industrial Revolution, What it Means, How We Respond. Available online: https://www.foreignaffairs.com/articles/2015-12-12/fourth-industrial-revolution (accessed on 10 March 2019).

41. Blaxter, L.; Hughes, C.; Tight, M. How to Research, 4th ed.; Open University Press: Buckingham, UK, 2010.

42. Gray, D. Doing Research in the Real World, 4th ed.; Sage: London, UK, 2018.

43. Crow, G.; Wiles, R.; Heath, S.; Charles, V. 'Research ethics and data quality: The implications of informed consent'. Int. J. Soc. Res. Methodol. 2006, 9, 83-95. [CrossRef]

44. Edmond, N.; Price, M. Professionalism in the children and young people's workforce. In Integrated Working with Children and Young People; Sage: London, UK, 2012; pp. 29-45. 
45. MacDermott, D.; McCall, S. The Supervisory Relationship within Practice Learning. In Doing Relationship-Based Social Work: A Practical Guide to Building Relationships and Enabling Change; McColgan, M., McMullin, C., Eds.; Jessica Kingsley: London, UK, 2017; pp. 147-163.

46. Dillenburger, K.; Godina, L.; Burton, M. Training in behavioral social work: A pilot study. Res. Soc. Work Pract. 1997, 7, 70-78. [CrossRef]

47. Scottish Social Services Council. Review of Social Work Education: Statement of Progress 2015-2016; SSSC: Edinburgh, UK, 2016.

48. Francis, R. Report of the Mid Staffordshire NHS Foundation Trust Public Inquiry; The Stationery Office: London, UK, 2013.

49. Donaldson, L. The Right Time, The Right Place: An Expert Examination of the Application of Health and Social Care Governance Arrangements for Ensuring the Quality of Care Provision in Northern Ireland; Department of Health: Belfast, UK, 2014.

50. Garrett, P.M. 'Transforming' Children's Services: Social Work, Neoliberalism and the 'Modern' World; Open University Press: Maidenhead, UK, 2009.

51. Garrett, P.M. Children and Families (Critical and Radical Debates in Social Work); The Policy Press: Bristol, UK, 2014.

52. Duncan-Daston, R.; Hunter-Sloan, M.; Fullmer, E. Considering the ethical implications of social media in social work education. Ethics Inf. Technol. 2013, 15, 35-43.

53. Northern Ireland Social Care Council. Standards of Conduct for Social Work Students; NISCC: Belfast, UK, 2015.

54. Goffman, E. The Presentation of Self in Everyday Life; Doubleday: New York, NY, USA, 1959.

55. Davys, D.; Pope, K.; Taylor, J. Professionalism, Prejudice and Personal Taste: Does it Matter What We Wear? Br. J. Occup. Ther. 2006, 69. [CrossRef]

56. Williams, D.J.; Thomas, J.; Christensen, C. 'You'll need to cover Your Tattoos!'. Reconsidering Standards of Appearance in Social Work. Soc. Work 2014, 59, 373-375. [CrossRef]

57. Terum, L.I.; Heggen, K. Identification with the social work profession: The impact of education. Br. J. Soc. Work 2016, 839-854. [CrossRef]

58. Department of Health. A Learning and Improvement Strategy for Social Workers and Social Care Workers 2019-2027; DoH: Belfast, UK, 2019.

59. Mezirow, J. How Critical Reflection Triggers Transformative Learning. In Fostering Critical Reflection in Adulthood: A Guide to Transformative and Emancipatory Learning; Mezirow, J., Ed.; Jossey-Boss: San Francisco, CA, USA, 1990.

60. Greenglass, E. 'Proactive coping' in Beyond Coping: Meeting Goals, Visions and Challenges; Frydenberg, E., Ed.; Open University Press: London, UK, 2002.

61. Pithouse, A. Social Work: The Social Organisation of an Invisible Trade, 2nd ed.; Ashgate: Aldershot, UK, 1998.

62. Hayes, D. Relationships Matter: An Analysis of Complaints about Social Workers to the Northern Ireland Social Care Council and the Patient and Client Council; NISCC: Belfast, UK, 2018.

63. McLaughlin, H. What's in a name: 'Client', 'Patient', 'Customer', 'Consumer', 'Expert by Experience', 'Service User'-What's next? Br. J. Soc. Work 2009, 39, 1101-1117. [CrossRef]

64. Hordern, J. Knowledge, Evidence, and the Configuration of Educational Practice. Educ. Sci. 2019, 9, 1-11. [CrossRef]

65. Barretti, M. What do we know about the professional socialization of our students? J. Soc. Work Educ. 2003, 40, 255-283. [CrossRef]

(C) 2019 by the author. Licensee MDPI, Basel, Switzerland. This article is an open access article distributed under the terms and conditions of the Creative Commons Attribution (CC BY) license (http://creativecommons.org/licenses/by/4.0/). 